DOI https://doi.org/10.30525/978-9934-588-86-0.18

\title{
DEVELOPMENT OF COST MANAGEMENT AND PRICING FOR PORT INDUSTRY (2015-2019)
}

\author{
Zhykharieva V. V., Oneshko S. V.
}

\section{INTRODUCTION}

Pricing in port industry is a strategic issue for Ukraine, carefully justified tariffs and port dues should become an important competitive advantage in the international market of stevedoring services. The task of creating competitive tariffs brings to the fore the cost management process, which should be aimed not only at minimizing costs, but also at the mechanism for making effective decisions, which will optimize costs, achieve maximum profit, both in the short and long term.

The existing system of port tariffs and dues in foreign ports has a higher degree of flexibility, which makes them attractive to ship owners. This makes it necessary to improve methodological approaches to the formation of port tariffs and dues in Ukraine, taking into account the world experience, based on a sound approach to cost management and the introduction of a controlling system for port enterprises. The competitive position of Ukrainian port enterprises is weak, primarily due to the insufficiently justified level of port dues and tariffs.

The transition to the use of flexible pricing for cargo handling operations for Ukrainian port enterprises requires the development of economically sound approaches to determining contractual rates for services.

Changes in the level of port tariffs are associated with a decrease or increase in the competitiveness of market participants in stevedoring services, so the decision to reduce or increase the level of port tariffs should be based on economic feasibility. Reduce port tariffs should be compensated by increased revenue from transshipment of additional cargo volumes and not accompanied by a corresponding increase in tariffs for freight related transport.

A significant factor that leads to the adoption of erroneous management decisions is the lack of a controlling system at enterprises, which is an important factor in improving the efficiency of the development of port enterprises.

The working hypothesis of the study is based on a set of theoretical, methodological, organizational and applied provisions, concerning which the use of cost management and controlling systems in the management of seaports will provide increased efficiency, will optimize approaches to port pricing. This was confirmed and developed during research; it was proved that 
the development of port enterprises should be systematic, covering not only the internal organization, but also the relationship with the subjects of the external environment.

The theoretical and methodical basis for solving the research tasks is the scientific research in the field of port economy and a systematic approach, General scientific research methods: the method of analogies (for studying the theory of pricing, cost management and controlling), the method of spatial and dynamic comparison (for analyzing cost management techniques and evaluating the effectiveness of the controlling system), analysis and synthesis (for determining the problematic aspects of managing port enterprises, forming port tariffs and dues), grouping and classification (for systematization of types of costs and methods of managing them, types of prices of port enterprises), expert assessments (for evaluating methods of forming port dues, break-even analysis, flexible budget and budgeting), economic and mathematical modeling (for evaluating the feasibility of outsourcing non-core business processes of a stevedoring company, optimizing the level of port fees, tariffs for loading and unloading and discounts from transport tariffs, evaluating the feasibility of implementing a controlling system in the activities of a stevedoring company).

The novelty lies in the development of new theoretical foundations for cost management, the development of methodological and methodological approaches to improve the formation of port dues and stevedoring tariffs in the ports of Ukraine, the further development of approaches to the formation and implementation of the controlling system at port enterprises.

\section{DEVELOPMENT OF THEORETICAL FOUNDATION FOR COST MANAGEMENT OF PORT INDUSTRY ENTERPRISES}

In a competitive environment, prices and tariffs for port services and port charges can become a competitive advantage of the port industry enterprises or its weak side, so the cost management process comes to the fore, which is a complex economic process and covers all the main areas of activity of the business entity. The main provisions of this research are aimed at determining the features of applying the general cost management theory of port industry enterprises in the pricing process.

Currently, the issues of evaluating the effectiveness of cost management of port industry enterprises, improving operational cost analysis, selecting tools for a process-oriented approach to determining the cost of port products and services, and economic evaluation of the feasibility of implementing business process outsourcing at port industry enterprises remain out of sight.

The formation of stevedoring tariffs and an economically justified level of port charges are based on approaches to cost management and their classification. It is established that there are more than 50 classification features of costs that are generalized and do not fully take into account the 
specific features of the activities of individual sectors of the economy. Therefore, in order to improve the management aspect of cost management, it is necessary to improve their classification by place of origin and responsibility centers. In addition, cost management is carried out by implementing a set of functions, for which various approaches, methods and techniques have been developed in modern Economics. In the process of cost management in domestic practice, "traditional" approaches are more often used, aimed at improving the calculation and control of costs for certain types of products. In turn, "market" approaches focus on ensuring control over the amount of expenses, the volume of products and the result of its implementation. The choice of the method is determined by the purpose of using the cost management system and the availability of conditions for their implementation.

The possibility of using operational analysis in determining prices for homogeneous products is studied in the work of A. G. Zhelamskaya ${ }^{1}$. The author has constructed an economic and mathematical model for determining the optimal structure of the price and cost of goods. On the example of a container terminal, a traditional margin analysis was performed, during which break-even points, loss and profit zones were determined. The work of A. S. Lesnik ${ }^{2}$ is devoted to modeling the dependence of cargo handling cost on the volume of cargo transshipment in sea ports.

The proposed method allows you to determine the cost price, cost and profitability of transshipment in the port of 1 ton of cargo of each name, both with the basic and modified volume of transshipment, and the possible amount of discounts from the current accord rates for cargo handling, with contractual volumes of cargo transshipment. The method assumes the linear nature of the cost dependencies on the cargo turnover, all expenses are shown in a directly proportional dependence on the volume of cargo, but in practice there are certain differences in the dependencies of different cost items on the cargo turnover. In addition, in the long term, the nature of dependencies is nonlinear. The existing research practically does not consider the specifics of conducting operational analysis methods in the formation of cargo handling costs. The analysis methods are developed under the conditions of the state monopoly on tariffs and are based on linear dependencies. Theoretical and practical aspects

${ }^{1}$ Zhelamskaya A. G. (2000) Upravlenie zatratami na osnove metodov operaczionnogo analiza [Cost management based on operational analysis methods]. St. Petersburg: St. Petersburg State University of Water Communications. (in Russian)

${ }^{2}$ Lesnik A. S. (1999) Modelirovanie zavisimosti sebestoimosti proizvodstva PRR ot ob'emov perevalki gruzov $\mathrm{v}$ portah [Modeling the dependence of the cost of production of cargo handling on the volume of transshipment of cargo in ports]. Rozvytok metodiv upravlinnia ta hospodariuvannia na transporti [Development of management and economics methods in transport industry], no. 4, pp. 102-116. 
of the implementation of a process-oriented approach to cost management are considered in the work of O. V. Korneva and A. G. Mnatsakanyan ${ }^{3}$, however, the specifics of the functioning of port industry enterprises are not defined, which is manifested in the use of significant production capacities, the presence of a significant share of indirect costs and a complex pricing system in the market conditions of management.

Methodical bases for evaluating the efficiency of outsourcing in the activities of marine transport are explored in the research of V.V. Ozarinska ${ }^{4}$, while there is no specific method of assessing the choice of outsourcing service provider, the risks of costs in the implementation of business process outsourcing and the criteria for evaluating the feasibility of implementing the outsourcing of non-core business processes have not been studied.

These problematic aspects of cost management of port industry enterprises are studied in the work of S.V. Oneshko ${ }^{5}$, which developed methodological bases for cost management of port enterprises in terms of operational analysis and approaches to cost management of port industry enterprises based on a process-oriented approach, identified differences in cost objects in the traditional and process-oriented approaches to the formation of the cost of port products, systematized business processes and proposed methodological bases for evaluating the effectiveness of cost management of port industry enterprises. In addition, an assessment of the feasibility of implementing outsourcing of non-core business processes in the activities of a stevedoring company was made, and a scheme for realization of outsourcing by realization stevedoring company was offered; a classification of risks in the implementation of outsourcing based on the "cause of occurrence"; identified areas for reducing costs by reducing business processes; methodological bases for implementing outsourcing of non-core business processes of a stevedoring company have been developed.

3 Korneva O. V., Mnatsakanyan A. G. (2016) Teoriya i praktika proczessnoorientirovannogo byudzhetirovaniya (na primere beregovy`kh ry`bopererabaty`vayushhikh predpriyatij Kaliningradskoj oblasti) [Theory and practice of process-oriented budgeting (on the example of coastal fish processing enterprises of the Kaliningrad region)]. Kaliningrad: Publishing House of FSBEI HPE "KSTU”. (in Russian)

${ }^{4}$ Ozarinska V. V. (2012) Autsorsynh yak perspektyvna forma vzaiemodii pidpryiemstv morskoho transportu [Outsourcing as a promising form of cooperation between marine transport]. Rozvytok metodiv upravlinnia ta hospodariuvannia na transporti [Development of management and economics methods in transport industry], no. 4, pp. 155-165.

${ }^{5}$ Oneshko S. V. (2015) Ekonomichni osnovy upravlinnia ekspluatatsiinymy vytratamy portovoho operatora [Economic basics of port operator operational cost management]. Odessa : The Institute of Market Problems and Economical \& Ecological Researches of the National Academy of Sciences of Ukraine. (in Ukrainian) 
Method of operating cost analysis is described in the study of S. V. Oneshko ${ }^{6}$. The research proposes a method of operational break-even analysis "costs - volume - profit" (CVP) to determine the optimal turnover of the port operator. This method, unlike the existing one, based on the nonlinear dependence of costs, revenue and profits from turnover, which allows not only to identify the traditional indicators, but also to study their dynamics, and to find two break-even points. Optimization of the volume of turnover port operator was conducted by constructing an economic and mathematical model under the criterion of maximum profit.

In the research S. V. Oneshko and M. O. Boiko ${ }^{7}$ proposed a methodical approach to implementation of the system of Activity Based Budgeting in the stevedoring company's activities as a tool for the management component of economic security by constructing a stevedoring company budgeting system taking into account the specifics of its business processes. Illustrated features of drawing budgets of stevedoring company, gives examples the overlay items and business processes on the budgets of the stevedoring companies and the combination of the budget structure of financial responsibility centers. The synergistic effect of the implementation shown in getting effective results at each stage of the implementation of activity-based budgeting and consistent with the objectives to ensure the development of strategies aimed at improving the economic and financial indicators.

Further developments in the direction of cost management are described in the monograph of S. V. Oneshko ${ }^{8}$, which considered the costs of a stevedoring company as an object of management, determined the classification of costs of a stevedoring company, and investigated approaches to the choice of a cost management method. The monograph offers methodological bases for evaluating the effectiveness of cost management of a stevedoring company, provide for the diagnosis of costs by the main components of the cost, service capacity and efficiency, and a methodological approach to the operational cost analysis, which is based on nonlinear dependencies of costs, revenue, and profit from cargo turnover, which allows you to find the optimal ratio of "results - costs".

${ }^{6}$ Oneshko S. V. (2015) Operatsiinyi analiz yak instrument upravlinnia vytratamy portovoho operatora [Operational analysis as a port operator's cost management tool]. Aktualni problemy ekonomiky [Topical problems of the economy], no. 2(164), pp. 442-449.

${ }^{7}$ Oneshko S.V., Boiko M.O. (2016) Activity-based budgeting as a management tool of economic security of stevedoring company. Economy: the realities of time, no. 3(25), pp. 134-143.

${ }^{8}$ Oneshko S.V. (2017) Ekonomichnyi instrumentarii upravlinnia vytratamy styvidornoi kompanii [Economic cost management tools stevedoring company]. Odessa: Interprint. (in Ukrainian) 
In addition, it is recommended to use the methodological bases of economic assessment of the feasibility of implementing non-core business processes by stevedoring companies, which are focused on optimizing the cost and time of the business process according to the criterion of maximum profit intensity and take into account the specifics of the port industry and the risk associated with outsourcing. The general results obtained regarding the theoretical foundations of cost management of port industry enterprises can be formed as follows:

- in order to improve management accounting and in connection with the structural changes that have occurred in the industry of port management, it is proposed to add to the existing classification feature "by cost centers and responsibility centers", which is an effective method for monitoring the results of activities with specific cost location;

- a methodological approach to operating cost analysis, which is based on nonlinear dependencies, costs, income, profit from turnover and allows to find the optimal ratio of "results - expenses", according to which settle in the base rate competitive tariff for port services and discounts and allowances to them, depending on the volume of the cargo claimed by the customer of the goods. This approach is an effective cost management tool for port industry enterprises and a basis for justifying competitive rates;

- an approach to selecting a cost management method has been developed that takes into account the characteristics of a stevedoring company's business (a significant share of fixed costs), the type of cargo (price elasticity), and the operating conditions;

- the methodological basis for evaluating the effectiveness of cost management of the stevedoring company has been developed, which provides for the diagnosis of costs by the main components of the cost, service capacity and efficiency, calculation of the integral indicator of cost management efficiency and evaluation of the ratio of its level with competitors;

- business processes are systematized, on the basis of which the stevedoring company's budgeting system is proposed and methodological bases for evaluating the cost management efficiency of port industry enterprises are developed on the basis of a process-oriented approach, which will improve the management efficiency and dynamic development in all areas and types of activities in order to prevent risks and financial losses from the use of available resources;

- suggested a process-oriented approach to determining the cost of port products and services in the pricing process, which provides for the proposed and justified allocation of the main and non-main business processes in the work of stevedoring companies, allows achieving the set strategic goals in conditions of limited resources and takes into account the specifics of business processes; 
- methodological bases for economic assessment of the feasibility of implementing non-core business processes by stevedoring companies have been developed, which are focused on optimizing the cost and time of the business process according to the criterion of maximum profit intensity and take into account the specifics of the port industry and the risk associated with outsourcing;

- developed the classification of the risk occurrence of costs in the implementation of outsourcing business processes of the stevedoring companies by introducing a classification attribute "the cause", according to which there are risks of incorrect choice of the business process (outsourcing) and contract on unfavorable terms in order to timely implement adequate measures to minimize the negative consequences;

- an economic tool has been developed to justify the choice of an outsourcer, which will allow optimizing the duration of business processes and the amount of expenses of a stevedoring company by using an economic and mathematical modeling tool adapted to the conditions of operation of stevedoring companies.

The results obtained in the course of the research acquire special significance today, due to significant changes in port legislation and in the framework of the policy of integration of national transport infrastructure into the European interregional transport system. The practical value of the results lies in the fact that the developed methodological bases are aimed at strengthening competitive advantages and allow increasing the efficiency of stevedoring companies and the port industry in Ukraine as a whole, reducing costs and improving management efficiency in a dynamic environment.

\section{DEVELOPMENT OF METHODOLOGICAL BASES FOR FORMATION OF THE TARIFFS AND DUES IN PORT INDUSTRY}

In the works of M. Acciaro ${ }^{9}$, T. Achmadi ${ }^{10}$, H. Meersman, S. Strandenes and E. de Voorde ${ }^{11}$, V. V. Popov ${ }^{12}$, N. I. Yudina ${ }^{13}$ and others, models of port pricing in certain countries in certain years are considered, but there is no

${ }^{9}$ Acciaro M. (2013) A Critical Review of Port Pricing Literature: What Role for Academic Research. The Asian Journal of Shipping and Logistics, vol. 29, no. 2, pp. 207-228. https://doi.org/10.1016/j.ajsl.2013.08.005Get

${ }^{10}$ Achmadi T., Hadi F., Nur H., Yunianto I., Boyke C. (2017). Study of Port Tariff Structure and Port Pricing Approach. Applied Mechanics and Materials, vol. 862, pp. 226-231. DOI: 10.4028/www.scientific.net/AMM.862.226

${ }^{11}$ Meersman H., Strandenes S., de Voorde E. (2014). Port Pricing: Principles, Structure and Models: discussion paper. Norwegian school of economics. URL: https://core.ac.uk/download/pdf/30803372.pdf (accessed 10.04.2020).

12 Popov V. V. (2013). Zarubezhnaya praktika portovogo tsenoobrazovaniya [International practice of port pricing]. Porty Ukrainy [Ports of Ukraine], no. 1, pp. 58-60.

${ }^{13}$ Yudina N. I. (2011) Portovye sbory kak sbory fiskal'noy prirody [Port dues as dues of fiscal nature]. Nalogi i nalogooblozhenie (Taxes and Taxation), no. 12, pp. 15-21. 
comprehensive systematization of the modern international experience of port pricing, which is performed in the study. This allowed us to develop a scientific understanding of pricing in the port industry, to elaborate a classification of prices for services of port enterprises, which takes into account approaches to regulating port tariffs in Ukraine.

Pricing is the most important factor in improving the efficiency of ports, which contributes to the development of the surrounding territories and the country as a whole. There are different trends in the world: the growth of relative independence and autonomy of ports, on the one hand, and the expansion of the competence of special bodies that are designed to coordinate the work of ports in the national interest, on the other. The latter trend is stronger, according to the authors, in the practice of developed countries.

An analysis of the main concepts of forming port dues and charges in ports allows us to find that there are two main approaches in the world - based on the English and French concepts. The modern English concept of port charges provides that ports should operate on the principles of self-sufficiency. Accordingly, the amounts of port dues, as the main and sometimes only source of funds to cover the related costs, should be based on real costs and include a certain share of profits. The French concept provides only partial coverage of the port's expenses through port dues. The rest of the financing is provided by the economic activities of the port itself, investments, and participation of state and local budgets in infrastructure development. This is logical, because the development of infrastructure leads to an increase in the number of jobs, the development of transport services and the growth of tax revenues.

Most port tariffs are based on the principle of providing all possible services to ensure the safety and security of the process of loading, further transportation and unloading of cargo. Basically, they are treated so that a port operator not only gets a fee for cargo handling, but also assumes the expense of the fare payment transactions on the preparation of cargo for loading and sea transportation to the port of shipment and of preparation of cargo for land transport at the port of destination, that is, on the basis of "From acceptance to the shipment" without prescribing loading and unloading rates.

In the works of S. V. Kivalov ${ }^{14}$, O. M. Kotlubai, I. V. Poznanska ${ }^{15}$ and others, the methodical and organizational aspects of the formation of port dues in seaports of Ukraine were considered. In the works of V. P. Vlasova,

14 Kivalov S. V. (2017) Portovi zbory v Ukraini: poshuk optymalnoi modeli konkurentnoi taryfnoi polityky [Port dues in Ukrain: searching of optimal model of competitive policy]. Lex Portus, no 1, pp. 5-21.

15 Kotlubai O. M., Poznanska I. V. (2018) Osoblyvosti mekhanizmu formuvannia portovykh zboriv $\mathrm{v}$ ukrainskykh portakh [Features of mechanism of port dues formation in Ukrainian ports]. Development of management and economics methods in transport industry, no. 2(63), pp. 131-140. DOI: 10.31375/ 2226-1915-2018-2-131-140 
T. O. Berehova and A. V. Pidhrushna ${ }^{16}$, O. M. Kibik ${ }^{17}$ and others the individual measures to improve port pricing have been studied, but there are no methodological approaches based on a systematic approach and provide for solving the problem of port pricing in the context of integrated industry regulation.

Port charges in the ports of Ukraine are considered as a source of funds for the maintenance and development of ports (water areas, berths, channels, fairways, breakwaters, coast protection structures, docks, etc.) and ensuring the safety of navigation in ports and approaches to them (including the maintenance of lighthouses, navigation equipment, pilotage services, icebreakers, radar control systems for vessel traffic, etc.).

Based on the study of the pricing system in the ports of Ukraine, a classification of prices for services of Ukrainian port enterprises is proposed, which takes into account existing approaches to regulating various types of port tariffs. Classification provides for the distribution of prices into two groups: prices that are regulated by the state, and free prices. Prices that are regulated by the state include prices for services that are paid as a part of port dues, and prices for specialized services provided in the seaport by natural monopolies. The latter include providing pilotage, regulating the sailing of vessels, ensuring icebreaking operations and ensuring access of the port operator to the berth, which is under the economic management of the SE "USPA", except for the berth, which is used by the port operator on the basis of a lease agreement, concession, joint activities concluded in accordance with legislation.

Free prices include stevedoring tariffs, tariffs for cargo storage in warehouses of ports, tariffs for the client's use of berths and port territory when performing cargo handling, tariffs for local cargo transportation by vessels of the port fleet, tariffs for other works and services provided to cargo owners, and tariffs for works and services paid by ship owners - mooring fee, payment for the work of tugs and other watercraft, tariffs for the services of the port master's service for registration of the arrival and departure of the vessel and sealing of locking devices, payment for the duty of a fire engine and specialist (for oil and gas carriers), services for boarding and disembarking passengers, water supply, tariffs for other services provided to ships both in foreign and coastal navigation), tariffs for services to passengers (visitors) tariffs for local transportation of passengers by port fleet vessels within one

${ }^{16}$ Vlasova V. P., Berehova T. O., Pidhrushna A. V. (2014) Portovi zbory v morskykh portakh Ukrainy [Port dues in sea ports of Ukraine]. Global and national economic problems, no. 2, pp. 431-435.

17 Kibik O. M. (2005) Teorija ta metodologhija cinoutvorennja v morsjkykh torghoveljnykh portakh [Theory and methodology of pricing in sea commercial ports]. Odesa: ONMU. (in Ukrainian) 
port (or port point) or between closely located ports that are the area of local navigation of vessels, excursions and other services provided by ports to passengers (visitors); tariffs for services to third-party organizations operating on the territory of the port.

The analysis of the level of port dues in Ukrainian ports and foreign ports, including competing ports, showed that the level of dues in Ukrainian ports is significantly higher, and this difference increases with the growth of ship tonnage $^{18}$. Despite a $20 \%$ reduction in port dues rates in 2018-2019, the level of port dues significantly exceeded the level of rates of foreign competing ports. In addition, Ukraine has the largest number of fees among competing ports.

The analysis of revenues and expenses of the SE "USPA" allows us to identify the role of port dues in the formation of financial results of the enterprise. The formation of the net income of the enterprise in the 68-72\% was due to the income from port dues, there is a tendency to reduction of specific weight with a slight increase in the share of revenues from pilotage services. In the structure of revenue from port dues, the dominant part is occupied by ship and canal dues.

A comparative analysis of existing draft methods for determining the size of the main port dues rates allowed us to propose a methodological approach based on cost and commercial pricing methods. It is proposed to use a combination of these methods while reducing the payment of part of the net income to the budget by state-owned port enterprises. Rates calculated on the basis of the cost approach should be adjusted to take into account the rates of competing ports based on the assessment of the level of clientele's costs when transporting goods through Ukrainian ports, taking into account the projected level of additional revenue that the state will receive from the development of regions adjacent to the ports. It should be taken into account that reducing the rates of port dues based on a combination of cost-based and commercial approaches will lead to a decrease in state budget revenues in the short term, and may also lead to a decrease in investment expenditures of port enterprises in the short term. However, in the long term, the solution of the above problems will make it possible to implement the main objectives of the National transport strategy of Ukraine until 2030 and the strategy for the development of seaports of Ukraine for the period up to 2038, thereby increasing the competitiveness of the port industry and ensuring its technological development, bring the standards of operation of seaports in line

${ }^{18}$ Zhikhareva V. V., Oneshko S. V. (2018) Sovershenstvovanie tsenoobrazovaniya V portovoy otrasli Ukrainy [Improvement of pricing in port industry of Ukraine]. Bulletin of transport and industrial economics, no. 63, pp. 82-95. DOI: $10.18664 / 338.47: 338.45 . v \%$ vi\%i.137578 
with European standards, create favorable conditions for the state to attract private investments in the development of port infrastructure, provide state guarantees and protection.

The decrease in port dues will be compensated in the macroeconomic context by an increase in revenues from transshipment of additional cargo volumes and transportation by other modes of transport. If the reduction of port dues to a competitive level makes it impossible to cover the costs of a particular port for the maintenance of relevant infrastructure elements, it is necessary to look for ways to reduce the cost of services, capital expenditures or compensate for part of the investment costs through credit, financial and tax incentives for port enterprises that have been well tested in international practice. The formation of port dues rates should be oriented on the level of competitiveness of ports in the region, taking into account the fact that cargo owners choose routes for delivery of goods based on the cost of all components of the transport logistics chain.

Methodological principles of building up the rates of port dues should include: the principle of transparency of mechanism of building up the level of port dues; the principle of compensation of all justified expenses; the principle of receiving of well-grounded net income including investment component; the principle of ensuring competitiveness of ports on the stevedoring market; the principle of the complex approach to determination of port dues rates, which provides assessment of additional revenues of state budget from development of regions adjacent to ports at a certain level of port dues; the principle of the differential approach to laying down port dues rates; the principle of purposeful character of use of port dues for direct support of port infrastructure in certain port.

The article by V. V. Zhikhareva and N. T. Ksandinov ${ }^{19}$ considers the problems of forming the rates for cargo handling operations in the ports of Ukraine under the conditions of liberalization. The consequences of free pricing for loading and unloading operations are revealed. The liberalization of loading and unloading tariffs with a simultaneous increase in the supply of stevedoring companies' services and the presence of problems with the legal regulation of public-private partnership has led to a significant reduction in loading and unloading tariffs, unequal competition conditions between stevedoring companies of different ownership forms, deterioration of financial results of stevedoring companies and a decrease in state budget allocations.

19 Zhikhareva V. V., Ksandinov N. T. (2018) Formirovanie tarifnykh stavok na pogruzochno-razgruzochnye raboty $\mathrm{v}$ portakh Ukrainy $\mathrm{v}$ usloviyakh liberalizatsii $\mathrm{i}$ gosudarstvenno-chastnogo partnerstva [Buildup of cargo handling tariffs in Ukrainian ports in conditions of liberalization and public-private partnership]. Development of management and economics methods in transport industry, no. 4(65), pp. 40-55. DOI: 10.31375/22261915-2018-4-40-58 
The directions of improvement of state regulation of pricing in Ukrainian ports are proposed: requirements for all port authorities of the country to adopt a unified pricing structure (subject to the freedom to set the basic rates), improvement of cost calculation methods and cost control systems for determining free rates, control of the overall level of port dues and fees for ship owners and cargo owners, which would be competitive from the point of view of logistics, optimization of rates for operators' access to the berth, improving concession legislation to improve the efficiency of public-private partnerships in seaports.

Methodological approaches have been developed to improve the state regulation of port pricing in Ukraine in the context of comprehensive regulation of the port industry.

It should be taken into account that in recent years, the actual total tax burden on the state-owned port enterprises in Ukraine has amounted to more than $90 \%$ of net profit. At the same time, in many ports of the EU, Asia and America, port dues are formed on the basis of the French concept. In the EU countries, subsidies are used for infrastructure development, while Ukrainian ports not only receive nothing from the state, but on the contrary pay taxes on port dues, which negatively affects their competitiveness. State-owned port enterprises are looking for investors, while giving the earned money to the state. The problem of state regulation of the port economy must be solved comprehensively. It is necessary to significantly reduce the deduction of part of the net profit of state-owned port enterprises. These funds should be used to modernize the port infrastructure, develop the material and technical base, and purchase port equipment.

Bureaucratic restrictions on the work of state ports relate to the disposal of property, earned funds, and personnel issues. This results in additional costs for maintaining obsolete fixed assets. These problems were increased by the bureaucratic state system of approving financial plans. This led to the fact that state-owned enterprises were not able to pay the necessary expenses even if they had money. There is a dependency: expensive ports - expensive transport component of export and transit cargo - decrease in cargo traffic - decrease in employment in the port sector and transport industry - increase in unemployment due to a drop in the population's ability to pay - decrease in state budget revenues.

To improve state regulation of the port enterprises, it is necessary to create equal conditions for the functioning of public and private port enterprises, reduce the regulatory and tax burden on state enterprises in order to create favorable, competitive conditions for their activities; improve the mechanism for implementing public-private partnership projects in seaports to attract investments. Taking into account the tasks of the state transport policy, the 
following main directions for improving the regulation of the port industry and port pricing in Ukraine are proposed:

- decrease in the share of deductions from the net profit of state-owned port enterprises;

- elimination of bureaucratic restrictions write-off of fixed assets, solution of personnel issues, elimination of the bureaucratic system for approving financial plans of state port enterprises;

- requirements for the entire port authority of the country to adopt a single pricing structure for cargo handling;

- improvement of the cost calculation methodology and cost control system for determining free cargo handling rates;

- improvement of the methodology for calculating the rates of port dues taking into account the cost of services, as well as the level of transport costs of clients in competing ports based on a combination of cost and commercial methods;

- control of the overall level of the port dues and charges for ship owners and cargo owners, which will be competitive in terms of logistics costs of the clientele, control of the basic level of individual port dues and charges of the privileged clientele of ports;

- optimization of rates for operators' access to the berth.

To prevent the loss of existing transit cargo flows, it is necessary to create conditions for their consolidation and development, to preserve the overall positive effect of transit for the national transport system, and to make changes to the methodology for determining the rates of port dues in order to optimize them for increasing cargo flows through Ukrainian seaports.

The decision on the level of port dues should be made within the framework of changing the general concept of state regulation of the port industry. Taking into account that port dues form only a part of the client's expenses for cargo delivery, it can be argued that it is not only the level of port dues that determines the market competitiveness of seaports. An unjustified reduction in port dues may make it impossible to realize sufficient investments in infrastructure, but it will not necessarily lead to increased port competitiveness and cargo traffic. Any increase in the level of port dues should take into account the level of competitiveness of ports in the region, taking into account the fact that cargo owners choose routes for delivery of goods not based solely on the level of port dues, but taking into account the cost of all components of the transport chain. 


\section{DEVELOPMENT OF THEORETICAL FOUNDATION FOR FORMATION AND IMPLEMENTATION OF CONTROLLING SYSTEM IN PORT INDUSTRY}

The formation and development of controlling in Ukraine is quite limited and is rarely used in the practice of business entities. Given the slow pace of economic development and the lack of effective tools for strategic and operational control at the enterprise management level, the importance of controlling increases. This fact is reinforced by arguments in the direction of economic consequences of incorrect management decisions in the form of monetary losses. The relevance of the research is caused by the reform processes taking place in the port sector, which are accompanied by a gradual transition from public sector to private, that is, the development is a mainly commercial nature: finding optimal volume loading and unloading, the optimal ratio of costs and tariffs to achieve maximum profit. For a stevedoring company, as a structural element of the port industry, such tasks are a priority, and their solution is possible through the implementation of a controlling system. The works of V. A. Budnik and E. L. Shkurko ${ }^{20}$, I. Yu. Potay ${ }^{21}$ and etc. consider the issues of implementing controlling in the port industry, present the composition of the controlling service, substantiate the feasibility of using the controlling system in the management of seaports in Ukraine, but there are no methodological recommendations for implementing controlling in the activities of stevedoring companies that take into account the specifics of their activities, economic and mathematical models of risk insurance at the stage of implementing the controlling system.

In the study S. A. Haluk ${ }^{22}$ conducted the comparative analysis of the use of the controlling system in the management of enterprises in different countries by the following factors: the most commonly used functions of controlling, methods of controlling, the industry and sphere of activity of the enterprisesusers of controlling, enterprise size and type of controlling, but not the

${ }^{20}$ Budnik V. A., Shkurko E. L. (2014) Kontrolinh taryfiv na perevalku vantazhiv v morskykh portakh Ukrainy [Controlling of tariffs for transshipment of cargo in the seaports of Ukraine]. Problemyi ekonomiki [Problems of economy], no. 2, pp. 100-107.

${ }^{21}$ Potay I. Yu. (2015) Kontrolinh u stratehichnomu planuvanni rozvytku morskykh portiv Ukrainy [Controlling in strategic planning of development of seaports of Ukraine]. Zbirnyk naukovykh prats Natsionalnoho universytetu korablebuduvannia [Collection of scientific works of the National University of Shipbuilding], no. 6(462), pp. 109-118.

${ }^{22}$ Khayluk S. O. (2005) Zakordonnyi dosvid vykorystannia systemy kontrolinhu v upravlinni finansamy pidpryiemstv [Foreign experience of using a controlling system in managing the finances of enterprises]. Visnyk Ukrainskoi akademii bankivskoi spravy [Bulletin of the Ukrainian Academy of Banking], no. 2(19), pp. 36-41. 
evaluation algorithm and list of key indicators of efficiency of used resources of the stevedoring company in the controlling system.

The research by N. V. Ryabovolenko ${ }^{23}$ suggests the use of a methodological controlling system for implementing competitive and economically justified rates of port fees, systematization of costs of port industry enterprises, but there are no analytical tools for cost analysis, and the use of process-oriented budgeting methods in the activities of a stevedoring company.

The approach to implementation of controlling system at enterprises of the port sector of Ukraine was considered in the study of S. V. Oneshko, M. O. Boiko ${ }^{24}$. The research substantiates the implementation of the controlling system at enterprises of the port sector and identifies the main stages of its implementation. The following methods were used in the work: theoretical synthesis, analysis and synthesis, historical, abstract-logical method, dialectic - in the study of theoretical foundations of the problem under study and in the formulation of conclusions and proposals. The systematization of scientific research has shown the need for introduction of controlling in the management system at enterprises of the port sector, due to the following main reasons: increased instability of the environment and the need for continuous tracking and increase the speed of reaction to its changes; the existence of disadvantages in terms of cost-effectiveness; significant deterioration of the main productive assets and inefficiency of investments; long distraction from the circulation of financial resources into accounts receivable; lack of tools for selecting relevant information; insufficient internal control and inconsistency of accounting policy with the requirements of the current legislation. The practical significance of the research carried out is that the main theoretical conclusions and methodological provisions are brought to the level of concrete practical recommendations and can be used in the activities of port enterprises to improve the efficiency of functioning.

The approach to the assessment of indicators efficiency of stevedoring companies in the controlling system is proposed in the study of S. V. Oneshko, A. R. Hryshchenko ${ }^{25}$. The research considered the system of efficiency

${ }^{23}$ Ryabovolenko N. V. (2017) Kontrolinh portovykh zboriv u morskykh portakh Ukrainy [Controlling of port charges in the seaports of Ukraine]. Problemy ekonomiky transportu [Problems of transport economy], no. 14, pp. 88-96.

${ }^{24}$ Oneshko S. V., Boiko M. O. (2019) New stages of development of modern science in Ukraine and EU countries: monograph: Approach to implementation of controlling system at enterprises of the port sector of Ukraine. Riga, Latvia: "Baltija Publishing", pp. 367-390. DOI: https://doi.org/10.30525/978-9934-588-15-0-41

25 Oneshko S. V., Hryshchenko A. R. (2019) Pidkhid do otsinky pokaznykiv efektyvnosti styvidornykh kompanii $\mathrm{v}$ systemi kontrolinhu [Approach to estimation of performance indicators of stevedoring companies in the controlling system]. Molodyi vchenyi [Young scientist], no 10. pp. 685-691. DOI: https://doi.org/10.32839/23045809/2019-10-74-144 
indicators included in the financial plan of the enterprise, defined criteria of evaluation efficiency of activity and evaluation of the financial plan implementation in terms of efficiency indicators of state stevedoring companies of Ukraine. It has been determined that the evaluation of the activity efficiency of enterprises can be carried out by a large list of criteria, the determining factor is the goals of the entities subject to assessment (managers, owners, investors, creditors, rating agencies, public authorities, competitors, etc.). Comprehensive assessment of the effectiveness of the business entity is usually performed on the basis of a specially developed or adapted system of indicators. On the example of state stevedoring companies of Ukraine given the estimation of the financial plan implementation on efficiency indicators and it is found that the plan is not fulfilled by the indicators. It is established that non-implementation of plans by state-owned stevedoring companies of Ukraine in terms of profitability indicates the need for increased attention to the managerial aspect in the search for reasons and decision-making aimed at remedying this situation, which is possible through the introduction of a controlling system, the main purpose of which is to orient the management achieving current and strategic goals to optimize financial results. Suggested the methodological approach, according to which companies are divided by efficiency indicators into categories, which allow determining the level of efficiency taking into account the trend of growth. It is recommended to use a matrix of evaluation efficiency indicators to determine the current status of the company and to provide guidance on the overall strategy. Using the proposed methodological approach will allow stevedoring companies to: coordinate management activities to achieve the chosen goal; support management decision-making; ensure the rationality of the management process to obtain the end result; eliminate "bottlenecks", ensure profitability and efficiency.

Resources of the stevedoring company as an object of controlling were considered in the research of S. V. Oneshko, D. A. Zdanevich ${ }^{26}$. The research designed the algorithm of evaluation and composition of key indicators of use efficiency of stevedoring company resources in the controlling system. This algorithm takes into account the presence of different types of deviations and is aimed at performing the main functions of controlling: accounting and control (comparison of planned and actual indicators) and prevention (risk prevention). The use of the proposed Key Performance Indicators is based on the analysis and diagnosis of the processes and factors impact in connection with business

${ }^{26}$ Oneshko S. V., Zdanevich D. A. (2019) Resursy styvidornoi kompanii yak obiekt kontrolinhu [Resources of a stevedoring company as an object of controlling]. Visnyk ekonomiky transportu i promyslovosti [Bulletin of transport and industrial economics], no. 67 , pp. 57-69. 
activities and will allow for a continuous process of monitoring and recording the planned and actual parameters of the stevedoring company to track the dynamics of change for each type of resources to improve efficiency.

Practical application of operating methods of controlling in the activities of the stevedoring company were considered in the research of S. V. Oneshko and E. I. Kulcha ${ }^{27}$. In the research application of operational methods of controlling in the activities of stevedoring companies is considered. The results of the analysis showed that the most appropriate from the point of view of profit maximization for the stevedoring company is the use of the following methods of operational controlling: break-even-analysis; $\mathrm{ABC}$-analysis; XYZ-analysis; flexible budget. It is established that the studied methods of operational controlling allow the stevedoring company: to find the most favorable ratio of variable costs per unit of fixed costs, prices and production volume, to determine the most priority cargoes from the position of profit maximization, to control the budget, to establish deviation of actual values from planned, to analyze the reasons and identify measures to remedy the situation. The use of operational controlling methods in the stevedoring company will increase the effectiveness of management decisions, as the availability of timely and relevant information provides transparency of business results, finances, processes and strategy, that is, contribute to improving economic efficiency. In addition, the studied methods of controlling will allow to more accurately monitoring the results of activity of stevedoring company and its structural divisions.

The general results of the research contain elements of scientific novelty, which consists in further development of methodological approaches to the formation and implementation of the controlling system at the enterprises of the port industry:

- systematized research on the formation and implementation of the controlling system in the enterprise, advantages and disadvantages of implementation with the allocation of goals, objectives and subject area of controlling;

- the necessity of implementing controlling in the management system of enterprises in the port industry is justified, which is due to: increased instability of the external environment and the need for continuous monitoring and increasing the speed of reaction to its changes; the existence of shortcomings in the efficiency of cost management; significant depreciation of fixed assets and inefficient investment, etc.;

${ }^{27}$ Oneshko S. V., Kulcha E. I. (2019) Praktychne zastosuvannia operatyvnykh metodiv kontrolinhu $\mathrm{v}$ diialnosti styvidornoi kompanii [Practical application of operational methods of controlling in the activity of stevedoring company]. Problemy systemnoho pidkhodu $v$ ekonomitsi [Problems of systematic approach in economy], no 6(74). pp. 99-107. DOI: https://doi.org/10.32782/2520-2200/2019-6-38 
- an organizational and economic approach to the implementation of controlling in stevedoring companies is proposed, which takes into account the specifics of their activities, current development trends and characteristics of objects;

- proposed the use of economic-mathematical models of insurance risks at the stage of implementation of the controlling system, which, unlike the classical approach, as the risk using standard deviation, which combines the sizes of the deviations and their probabilities separately allocate risk ratio (amount of loss) and the probability of loss as the two independent characteristics of risk;

- developed the algorithm of evaluation and a list of key indicators of efficiency of use of resources of the stevedoring company in the controlling system, taking into account the peculiarities of its functioning and, along with the traditional indicators of efficiency, including the assessment of efficiency of use of energy as a significant expenditure stevedoring company level service capacity and the effect of innovation on the consumption of a specific resource, including the reduction of emissions into the environment;

- an approach to assessing the performance of stevedoring companies has been developed, according to which companies are divided by performance indicators into categories that allow determining the level of efficiency taking into account the trend of indicators. It is recommended to use a matrix for evaluating performance indicators, according to which it is possible to determine the current state of a stevedoring company and get recommendations for the formation of an overall development strategy;

- an analytical tool for cost analysis of a stevedoring company using break-even analysis, ABC analysis and flexible budget is proposed;

- the stages of economic justification of the investment project for the construction of a cargo berth in a seaport are proposed, their content and a set of factors that should be taken into account in the course of SWOT analysis are clarified;

- the method of process-oriented budgeting in the stevedoring company's activities has been further developed as a management tool based on the construction of a system of budgets taking into account the specifics of business processes.

The use of the obtained scientific results will allow stevedoring companies to: coordinate management activities to achieve the selected goal; support management decision-making, ensure the rationality of the management process of obtaining the final result; eliminate "bottlenecks" and ensure profitability and efficiency. 


\section{CONCLUSIONS}

The results of the study of the methodological foundations for the formation of tariffs and dues in the port economy, organizational and methodological provisions for evaluating the effectiveness of cost management, the formation of a controlling system and the mechanism for its implementation in the port industry can be implemented in the practice of port industry enterprises to improve the efficiency of the cost management process, conduct operational analysis, evaluate the effectiveness of cost management of port industry enterprises based on a process-oriented approach, evaluating the feasibility of outsourcing non-core business processes of a stevedoring company. It should be taken into account that reducing the rates of port dues founded on a combination of cost-based and commercial approaches will lead to a decrease in state budget revenues in the short term aspect, and may also lead to a decrease in investment costs of port enterprises in the short term aspect. However, in the long term aspect, the solution of the above-mentioned problems will make it possible to implement the main objectives of the National Transport Strategy of Ukraine 2030 and the Port Development Strategy of Ukraine 2038, thereby increasing the competitiveness of the port industry, ensuring its technological development, bring the standards of operation of seaports in line with European ones, create favourable conditions for the state to attract private investments in the development of port infrastructure, ensure their state guarantees and protection. The reduction in port prices should be compensated in the macro-economic context by an increase in revenues from transhipment of additional volumes of cargo and transportation by adjacent modes of transport. The formation of the level of port dues should take into account the level of competitiveness of ports in the region, taking into account the fact that cargo owners choose routes for delivery of goods based on the cost of all components of the logistic chain.

The main directions of improving the state regulation of port pricing in the ports of Ukraine include: requirements for all port authorities in the country to adopt a single pricing structure (subject to the freedom to basic rates), improvement of the cost calculation methodology and cost control system for determining free rates, control of the overall level of port charges for ship owners and cargo owners, which would be competitive from the point of view of logistics, optimization of rates for operator access to the berth, improving concession legislation to improve the efficiency of public-private partnerships in seaports.

Theoretical foundations and methodological approaches have been developed to improve the efficiency of the functioning and development of the port industry, prevent the loss of existing transit cargo flows, create conditions for their development, and preserve the overall positive effect of transit for the national transport system. 


\section{SUMMARY}

Development of methodological approaches to pricing of port industry enterprises scientifically based on the laws of functioning and development of maritime industry. Useful methodological developments based on practical experience for port industry enterprises are the classification of loading and unloading costs by responsibility and cost centers; methodological bases for choosing a method for managing costs of port enterprises; methodological bases for evaluating the effectiveness of cost management of port enterprises and comparing them with competitors; methodological approach to operational cost analysis of port enterprises; tools for a process-oriented approach to determining the cost of port services. It is proved that the decision to determine port tariffs and dues should be made within the framework of changing the general concept of state regulation of the port industry. Optimization of port tariffs should have a long-term multiplier effect on the development of related activities. Scientific-based organizational and economic approach to the implementation of controlling in the activities of stevedoring companies, the use of economic and mathematical models of risk insurance at the stage of implementing the controlling system; an algorithm for evaluating and listing key performance indicators for the use of stevedoring company resources in the controlling system, analytical tools for cost analysis of stevedoring companies using break-even analysis, $\mathrm{ABC}$ analysis and flexible budget; identification of threats and risks of port industry enterprises in general and risks associated with investment projects in seaports, as well as approaches to their quantitative assessment. The results obtained are related to the development of the Ukrainian economy and are aimed at attracting additional cargo flows and improving the financial results of the port economy and the general welfare of society.

\section{REFERENCES}

1. Zhelamskaya A. G. (2000) Upravlenie zatratami na osnove metodov operaczionnogo analiza [Cost management based on operational analysis methods]. St. Petersburg: St. Petersburg State University of Water Communications. (in Russian)

2. Lesnik A. S. (1999) Modelirovanie zavisimosti sebestoimosti proizvodstva PRR ot ob'emov perevalki gruzov $\mathrm{v}$ portah [Modeling the dependence of the cost of production of cargo handling on the volume of transshipment of cargo in ports]. Development of management and economics methods in transport industry, no. 4, pp. 102-116.

3. Korneva O. V., Mnatsakanyan A. G. (2015) Teoriya i praktika protsessno-orien-tirovannogo byudzhetirovaniya (na primere beregovyih ryiboobrabatyivayus-chih predpriyatiy Kaliningradskoy oblasti) [Theory and 
practice of process oriented budgeting (on the example of coastal fish processing enterprises of the Kaliningrad region)]. Kaliningrad: Publishing House of FSBEI HPE "KSTU”. (in Russian)

4. Ozarinska V. V. (2012) Autsorsynh yak perspektyvna forma vzaiemodii pidpryiemstv morskoho transportu [Outsourcing as a promising form of cooperation between marine transport]. Development of management and economics methods in transport industry, no. 4, pp. 155-165.

5. Oneshko S. V. (2015) Ekonomichni osnovy upravlinnia ekspluatatsiinymy vytratamy portovoho operatora [Economic basics of port operator operational cost management]. Odessa: The Institute of Market Problems and Economical \& Ecological Researches of the National Academy of Sciences of Ukraine. (in Ukrainian)

6. Oneshko S. V. (2015) Operatsiinyi analiz yak instrument upravlinnia vytratamy portovoho operatora [Operational analysis as a port operator's cost management tool]. Topical problems of the economy, no. 2(164), pp. 442-449.

7. Oneshko S. V., Boiko M. O. (2016) Activity-based budgeting as a management tool of economic security of stevedoring company. Economy: the realities of time, no. 3(25), pp. 134-143.

8. Oneshko S. V. (2017) Ekonomichnyi instrumentarii upravlinnia vytratamy styvidornoi kompanii [Economic cost management tools stevedoring company]. Odessa: Interprint. (in Ukrainian)

9. Acciaro M. (2013) A Critical Review of Port Pricing Literature: What Role for Academic Research. The Asian Journal of Shipping and Logistics, vol. 29, no. 2, pp. 207-228. DOI: https://doi.org/10.1016/j.ajsl.2013.08.005Get

10. Achmadi T., Hadi F., Nur H., Yunianto I., Boyke C. (2017) Study of Port Tariff Structure and Port Pricing Approach. Applied Mechanics and Materials, vol. 862, pp. 226-231. DOI: 10.4028/www.scientific.net/ AMM.862.226

11. Meersman H., Strandenes S., deVoorde E. (2014) Port Pricing: Principles, Structure and Models: discussion paper. Norwegian school of economics. URL: https://core.ac.uk/download/pdf/30803372.pdf (accessed 10.04.2018).

12. Popov V. V. (2013) Zarubezhnaya praktika portovogo tsenoobrazovaniya [International practice of port pricing]. Ports of Ukraine, no. 1, pp. 58-60.

13. Yudina N. I. (2011) Portovye sbory kak sbory fiskal'noy prirody [Port dues as dues of fiscal nature]. Taxes and Taxation, no. 12, pp. 15-21.

14. Kivalov S. V. (2017) Portovi zbory v Ukraini: poshuk optymalnoi modeli konkurentnoi taryfnoi polityky [Port dues in Ukrain: searching of optimal model of competitive policy]. Lex Portus, no 1, pp. 5-21.

15. Kotlubai O. M., Poznanska I. V. (2018) Osoblyvosti mekhanizmu formuvannia portovykh zboriv $\mathrm{v}$ ukrainskykh portakh [Features of mechanism 
of port dues formation in Ukrainian ports]. Development of management and economics methods in transport industry, no. 2(63), pp. 131-140. DOI: 10.31375/ 2226-1915-2018-2-131-140

16. Vlasova V. P., Berehova T. O., Pidhrushna A. V. (2014) Portovi zbory v morskykh portakh Ukrainy [Port dues in sea ports of Ukraine]. Global and national economic problems, no. 2, pp. 431-435.

17. Kibik O. M. (2005) Teorija ta metodologhija cinoutvorennja v morsjkykh torghoveljnykh portakh [Theory and methodology of pricing in sea commercial ports]. Odesa: ONMU. (in Ukrainian)

18. Zhikhareva V. V., Oneshko S. V. (2018) Sovershenstvovanie tsenoobrazovaniya $\mathrm{v}$ portovoy otrasli Ukrainy [Improvement of pricing in port industry of Ukraine]. Bulletin of transport and industrial economics, no. 63, pp. 82-95. DOI: 10.18664/338.47:338.45.v \%vi \%i.137578

19. Zhikhareva V. V., Ksandinov N. T. (2018) Formirovanie tarifnykh stavok na pogruzochno-razgruzochnye raboty $\mathrm{v}$ portakh Ukrainy $\mathrm{v}$ usloviyakh liberalizatsii i gosudarstvenno-chastnogo partnerstva [Buildup of cargo handling tariffs in Ukrainian ports in conditions of liberalization and public-private partnership]. Development of management and economics methods in transport industry, no. 4(65), pp. 40-55. DOI: 10.31375/2226-1915-2018-4-40-58

20. Budnik V. A., Shkurko E. L. (2014) Kontrolinh taryfiv na perevalku vantazhiv $\mathrm{v}$ morskykh portakh Ukrainy [Controlling of tariffs for transshipment of cargo in the seaports of Ukraine]. Problems of economy, no. 2, pp. 100-107.

21. Potay I. Yu. (2015) Kontrolinh u stratehichnomu planuvanni rozvytku morskykh portiv Ukrainy [Controlling in strategic planning of development of seaports of Ukraine]. Collection of scientific works of the National University of Shipbuilding, no. 6(462), pp. 109-118.

22. Khayluk S. O. (2005) Zakordonnyi dosvid vykorystannia systemy kontrolinhu $\mathrm{v}$ upravlinni finansamy pidpryiemstv [Foreign experience of using a controlling system in managing the finances of enterprises]. Bulletin of the Ukrainian Academy of Banking, no. 2(19), pp. 36-41.

23. Ryabovolenko N. V. (2017) Kontrolinh portovykh zboriv u morskykh portakh Ukrainy [Controlling of port charges in the seaports of Ukraine]. Problems of transport economy, no. 14, pp. 88-96.

24. Oneshko S. V., Boiko M. O. (2019) New stages of development of modern science in Ukraine and EU countries: monograph. Approach to implementation of controlling system at enterprises of the port sector of Ukraine. Riga, Latvia: "Baltija Publishing", pp. 367-390. DOI: https://doi.org/10.30525/978-9934-588-15-0-41

25. Oneshko S. V., Hryshchenko A. R. (2019) Pidkhid do otsinky pokaznykiv efektyvnosti styvidornykh kompanii $\mathrm{v}$ systemi kontrolinhu [Approach to estimation of performance indicators of stevedoring companies 
in the controlling system]. Young scientist, no. 10, pp. 685-691. DOI: https://doi.org/10.32839/2304-5809/2019-10-74-144

26. Oneshko S. V., Zdanevich D. A. (2019) Resursy styvidornoi kompanii yak obiekt kontrolinhu [Resources of a stevedoring company as an object of controlling]. Bulletin of transport and industrial economics, no. 67, pp. 57-69.

27. Oneshko S. V., Kulcha E. I. (2019) Praktychne zastosuvannia operatyvnykh metodiv kontrolinhu v diialnosti styvidornoi kompanii [Practical application of operational methods of controlling in the activity of stevedoring company]. Problems of systematic approach in economy, no. 6(74), pp. 99-107. DOI: https://doi.org/10.32782/2520-2200/2019-6-38

\section{Information about the authors:}

Zhykharieva V. V.,

Prof, Dr. in Economics,

Head of Economics and Finance Department,

Odessa National Maritime University

34, Mechnikov str., Odessa, 65000, Ukraine

ORCID ID: orcid.org/0000-0002-2179-8483

Oneshko S. V., $\mathrm{PhD}$ in Economics, Associate Prof. at the Economics and Finance Department, Odessa National Maritime University 34, Mechnikov str., Odessa, 65029, Ukraine ORCID ID: orcid.org/0000-0003-2313-3984 